\title{
Desastre da mineração em Barcarena, Pará e cobertura midiática: diferenças de duração e direcionamentos de escuta
}

\author{
Mining disaster in Barcarena, Pará and media coverage: differences in \\ duration and listening directions
}

\author{
Desastre minero en Barcarena, Pará y cobertura mediática: diferencias \\ en duración y direcciones de escucha
}

\author{
Rosane Albino Steinbrenner ${ }^{1, a}$ \\ nani.steinbrenner@gmail.com | https://orcid.org/oooo-0o03-4321-7245 \\ Guilherme Guerreiro Neto ${ }^{1, b}$ \\ gguerreironeto@gmail.com | https://orcid.org/o00o-0002-0733-9010 \\ Pedro Loureiro de Bragança ${ }^{1, c}$ \\ pedrohloureiro@gmail.com | https://orcid.org/oooo-0003-2910-2871 \\ Edna Maria Ramos de Castro ${ }^{1, d}$ \\ edna.mrcastro@gmail.com | https://orcid.org/oooo-0oo2-1764-6997 \\ ${ }^{1}$ Universidade Federal do Pará, Núcleo de Altos Estudos Amazônicos. Belém, PA, Brasil. \\ a Doutorado em Desenvolvimento Socioambiental pela Universidade Federal do Pará. \\ b Mestrado em Jornalismo pela Universidade Federal de Santa Catarina. \\ c Mestrado em Planejamento do Desenvolvimento pela Universidade Federal do Pará. \\ ${ }^{\mathrm{d}}$ Doutorado em Sociologia pela Ecoledes Hautes Etudes.
}

\section{Resumo}

O artigo objetiva analisar a cobertura midiática do desastre socioambiental ocorrido em 2018, em Barcarena, no Pará, e discutir tanto as diferenças entre a duração do desastre (prolongada) e a duração da cobertura (concentrada), quanto os direcionamentos de escuta entre a repercussão de eventos gerados por vozes oficiais/institucionais e a presença/ausência de vozes populares de comunidades e movimentos sociais. Como resultado, apresenta três momentos de análise dos dados coletados em clipping nacional ao longo de oito meses: uma análise quantitativa da frequência da cobertura indicando alcance e duração da visibilidade midiática; um recorte quanti-quali apontando como a mídia agenda e promove enquadramento por meio das fontes acionadas na produção da notícia; e uma análise qualitativa, na perspectiva decolonial, de como aparecem na cobertura do desastre as vozes historicamente silenciadas. Para compreender o desastre como processo, busca-se antes situar o contexto da mineração na Amazônia a partir do aporte da Ecologia Política.

Palavras-chave: Desastre; Mineração; Barcarena; Cobertura midiática; Ecologia Política; Perspectiva decolonial. 


\begin{abstract}
The article aims to analyze the media coverage of the socio-environmental disaster that occurred in 2018 , in Barcarena, Pará, and to discuss both the differences between the duration of the disaster (prolonged) and the duration of the coverage (concentrated), as well as the listening directions between the repercussion events generated by official/institutional voices and the presence/absence of popular voices from communities and social movements. As a result, it presents three moments of analysis of data collected in national clipping over eight months: a quantitative analysis of the frequency of coverage indicating reach and duration of media visibility; a quanti-quali cut pointing out how the media schedules and promotes framing through the sources used in the production of the news; a qualitative analysis, in the decolonial perspective, of how historically silenced voices appear in the coverage of the disaster. To understand disaster as a process, we first seek to situate the context of mining in the Amazon from the perspective of Political Ecology.
\end{abstract}

Keywords: Disaster; Mining; Barcarena; Media coverage; Political Ecology; Decolonial perspective.

\title{
Resumen
}

El artículo tiene como objetivo analizar la cobertura mediática del desastre socioambiental ocurrido en 2018, en Barcarena, en Pará, y discutir tanto las diferencias entre la duración del desastre (prolongada) y la duración de la cobertura (concentrada) en cuanto a los direccionamientos de la escucha entre la repercusión de eventos generados por voces oficiales/institucionales y la presencia/ausencia de voces populares de comunidades y movimientos sociales. Como resultado, presenta tres momentos de análisis de los datos recogidos en clipping nacional a lo largo de ocho meses: un análisis cuantitativo de la frecuencia de la cobertura indicando alcance y duración de la visibilidad mediática; un recorte cuanti-quali señalando cómo los medios de comunicación agenda y promueve encuadre a través de las fuentes impulsadas en la producción de las noticias; y un análisis cualitativo, desde la perspectiva decolonial, de cómo aparecen en la cobertura del desastre las voces históricamente silenciadas. Para entender el desastre como proceso se busca, primero, situar el contexto de la minería en la Amazonía a partir del aporte de la Ecología Política.

Palabras clave: Desastre; Minería; Barcarena; Cobertura mediática; Ecología Política; Perspectiva decolonial.

Este artigo pertence ao dossiê Comunicação e Meio Ambiente.

Contribuição dos autores:

Concepção e desenho do estudo: Guilherme Guerreiro Neto e Edna Maria Ramos de Castro.

Aquisição, análise ou interpretação dos dados: Pedro Loureiro de Bragança e Guilherme Guerreiro Neto e Rosane Albino Steinbrenner.

Redação do manuscrito: Rosane Albino Steinbrenner, Guilherme Guerreiro Neto, Pedro Loureiro de Bragança.

Revisão crítica do conteúdo intelectual: Rosane Albino Steinbrenner, Guilherme Guerreiro Neto e Edna Maria Ramos de Castro.

Declaração de conflito de interesses: não há.

Fontes de financiamento: não houve.

Considerações éticas: não há.

Agradecimentos: às comunidade de Barcarena, aos integrantes do Grupo de Pesquisa Estado, Território, Trabalho e Mercados Globalizados/Núcleo de Altos Estudos Amazônicos (GETTAM/NAEA) - Universidade Federal do Pará, à Capes e ao Conselho Nacional de Desenvolvimento Científico e Tecnológico (CNPq).

Histórico do artigo: submetido: 23 fev. 2020 | aceito: 10 maio 2020 | publicado: 30 jun. 2020.

Apresentação anterior: Parte dos dados empíricos analisados neste artigo foram apresentados preliminarmente em textos do Dossiê Desastres e Crimes da Mineração em Barcarena, de 2019.

Licença CC BY-NC atribuição não comercial. Com essa licença é permitido acessar, baixar (download), copiar, imprimir, compartilhar, reutilizar e distribuir os artigos, desde que para uso não comercial e com a citação da fonte, conferindo os devidos créditos de autoria e menção à Reciis. Nesses casos, nenhuma permissão é necessária por parte dos autores ou dos editores. 


\section{Introdução}

A empresa Hydro Alunorte - que faz parte da norueguesa Norsk Hydroi, maior corporação do setor de alumínio do mundo - produziu em fevereiro de 2018 no município de Barcarena, nordeste paraense, um dos mais significativos desastres socioambientais já ocorrido na Amazônia. Ele se deu com o vazamento de lama vermelha tóxica de um de seus depósitos de rejeitos que funcionava sem licenciamento válido, contaminando rios e o ecossistema de várzea, na foz do rio Amazonas. Moradores da região foram atingidos e comunidades mais próximas à empresa ficaram sem água para beber e para uso doméstico, além de serem impedidas de pescar para se alimentar.

Apesar das evidências de contaminação, constatadas já nos primeiros dias após o vazamento pelas denúncias da população local e por vistorias e perícias realizadas por órgãos federais e estaduais - entre os quais Instituto Evandro Chagas (IEC), Laboratório de Química Analítica e Ambiental da Universidade Federal do Pará (Laquanam/UFPA), Ministério Público Federal do Pará (MPF-PA), Ministério Público do Estado do Pará (MPPA) -, a Hydro Alunorte negou o transbordamento da bacia de rejeitos e qualquer responsabilidade sobre o caso. Tardiamente, reconheceu a existência de tubulação clandestina, que lançava material contaminado direto nos rios próximos à indústria. Somente seis meses depois do ocorrido a empresa assinou o Termo de Compromisso de Ajustamento de Conduta (TAC), que previa ações emergenciais e auditorias sobre a segurança da sua planta de refinamento de bauxita.

A impunidade tem sido uma das marcas das práticas coloniais de empresas de mineração em toda a América Latina $^{1-3}$. No município de Barcarena, maior polo de beneficiamento mineral no Pará, em 19 anos, foram registrados 26 desastres/crimes ambientais (ver quadro 1). Reportagens publicadas por ocasião do desastre de 2018 apontavam que a Alunorte respondia a 2 mil processos judiciais por contaminação de rios e comunidades de Barcarena ${ }^{\text {ii }}$ e devia 17 milhões de reais em multas por outro transbordamento de lama tóxica em 2009iii. As pressões dos movimentos sociais têm tido papel importante para revelar e cobrar soluções. O clima, entretanto, é de tensão e de sofrimento prolongado, contabilizando mais de três décadas desde a instalação no município de empreendimentos ligados à produção de commodities, que transformaram Barcarena em zona de sacrifício com recorrentes desastres socioambientais, como detalharemos a seguir.

O objetivo do presente artigo é analisar a cobertura midiática do desastre socioambiental ocorrido em 17 de fevereiro de 2018 no município de Barcarena, no Pará - envolvendo a norueguesa Hydro Alunorte e denunciado pelas comunidades locais - e discutir tanto as diferenças entre a duração do desastre (prolongada) e a duração da cobertura (concentrada) quanto os direcionamentos de escuta entre a repercussão de eventos gerados por vozes oficiais/institucionais e a presença/ausência de vozes populares das comunidades e dos movimentos sociais.

As primeiras notícias sobre o desastre foram publicadas dois dias após a denúncia do ocorrido, em 19 de fevereiro. No período de recorte do estudo, que envolve cerca de oito meses ou mais precisamente 243 dias de cobertura do acontecimento e seus desdobramentos, foram analisadas 1.322 notícias publicadas em mídias diversas - jornais impressos, emissoras de TV abertas e por assinatura, sites de jornalismo, blogs

\footnotetext{
i A Norsk Hydro atua há mais de 50 anos no mercado internacional com exportação para dez países no Oriente Médio, América do Norte e Europa. Trata-se de uma corporação norueguesa de capital aberto, estando mais de $50 \%$ sob controle do governo daquele país. No Brasil, possui um total de 11 empresas, sendo que é no estado do Pará que possui sua mina de lavra de bauxita, em Paragominas, e o complexo industrial Albras/Alunorte em Barcarena. O projeto Hydro Alunorte é a maior refinaria de alumina do mundo. Já a Albras, é a segunda maior fábrica de alumínio do Brasil.

ii G1 Pará. Parecer técnico aponta riscos na extração de bauxita feita pela Hydro em Paragominas [Internet]. 2018 [citado em 2019 maio 28]. Disponível em: https://g1.globo.com/pa/para/noticia/2018/07/30/novo-laudo-aponta-que-contaminacao-da-mineradohydro-em-barcarena-veio-de-paragominas.ghtml.

iii G1 Pará. Mineradora norueguesa tinha 'duto clandestino' para lançar rejeitos em nascentes amazônicas [Internet]. 2018 [citado em 2019 maio 28]. Disponível em: https://g1.globo.com/pa/para/noticia/mineradora-norueguesa-tinha-duto-clandestino-para-lancarrejeitos-em-nascentes-amazonicas.ghtml.
} 
e emissoras de rádio - locais, regionais e nacionais. Foram detectadas também, ainda que indiretamente, matérias que circularam por agências internacionais de notícia.

A coleta de dados se deu por meio de palavra-chave, em clipping nacional diário, e permitiu momentos distintos de análise. O que pretendemos é, primeiramente, apresentar quantitativamente a frequência da cobertura pela imprensa do desastre de Barcarena, no sentido de indicar o alcance e duração de sua visibilidade midiática, buscando compreender os diferentes tempos existentes entre o desastre como acontecimento público e processo desdobrado ao longo do tempo, e sua visibilidade midiática episódica e concentrada. Em um segundo momento, que por sua vez se desdobra em duas etapas, pretendemos analisar com elementos quanti-quali como aparecem na cobertura do desastre as vozes historicamente silenciadas de comunidades e movimentos sociais; tanto pelo entendimento de como a mídia agenda e promove o enquadramento do desastre socioambiental por meio da escolha das fontes acionadas na produção da notícia como buscando sinalizar e refletir, a partir de uma perspectiva decolonial, sobre a presença/ausência de comunidades atingidas e movimentos sociais na cobertura do desastre socioambiental.

Algumas noções conceituais aqui utilizadas merecem ser destacadas. Entendemos acontecimento em uma perspectiva pragmatista defendida por Louis Queré4, como apontado por Vera França e Suzana Lopes 5 , referido a "uma ocorrência, um fato concreto do cotidiano com grande poder de afetação, que suscita inquietações, demanda escolhas e provoca ações (...), convoca e revela sentidos, que dizem da sociedade na qual ele ocorre”. De tal sorte, "A potencialidade do acontecimento reside no desafio de identificar, através dele, tendências que apontam para a preservação e/ou renovação da vida social” ${ }^{5}$.

Já a constituição de um acontecimento em notícia, conforme Nelson Traquina ${ }^{6}$, significa dar-lhe existência pública ao inseri-lo como recurso de discussão a partir de um campo social7 especializado, no caso, o campo jornalístico. Nesse sentido, pode-se entender, como explica Traquina, que os acontecimentos são o ponto de partida para a construção dos enquadramentos midiáticos. E esses enquadramentos também atuam na formação dos acontecimentos - na medida em que os moldam enquanto narrativa, passam a ser parte deles. Enquadramento, na perspectiva de Mauro Porto ${ }^{8}$, vai no sentido de 'marcos interpretativos', construídos socialmente e utilizados pela mídia para buscar essa aproximação dos acontecimentos e o conhecimento social. Tais marcos interpretativos se delineiam por sua vez, a nosso ver, previamente, na disputa desigual entre os atores sociais pelo poder de atuar como fonte de informação, de virem a ser entrevistados e assim tornarem-se o definidor primário ${ }^{9}$ da notícia, matéria-prima do campo jornalístico.

O que nos moveu, inicialmente, foi o interesse em refletir sobre a dimensão de visibilidade e a polifonia de vozes (fontes) acionadas em torno da cobertura midiática de um desastre socioambiental no interior da Amazônia, com atenção especial ao tratamento recebido e o espaço ocupado pelas comunidades atingidas, seus moradores e representantes, nas notícias publicadas pela imprensa sobre o assunto. Levou-se em conta o papel central da mídia na mediação e construção de sentidos e, mais especificamente, da chamada grande imprensa na construção social da realidade, mas também as marcas das colonialidades ${ }^{10}$ presentes na prática discursiva midiática. Colonialidades entendidas como visões de mundo erigidas por padrão ou matriz colonial de poder, com base na naturalização de determinadas hierarquias de classificação social (raciais, territoriais, culturais, epistêmicas, de gênero), que, interseccionadas, (re)produzem cotidianamente subalternidades e invisibilidades recorrentes.

Mesmo considerando a intensa midiatização da sociedade em que vivemos, que atravessa os diversos campos sociais, o exercício do jornalismo ainda responde pela função primordial de informar os indivíduos sobre os acontecimentos do mundo, em um processo de construção social permeado por tensões e disputas. O acionamento das fontes presentes nos noticiários revela uma seleção que, ainda que técnica, nunca é neutra, e destaca e promove certas visões em geral vinculadas a uma correlação hegemônica das forças sociais em jogo. Entretanto, quanto mais plurais as posições de fala e as opiniões ouvidas, maiores as 
chances de uma prática jornalística que favoreça o exercício democrático do debate plural no espaço público da arena midiática.

Nesse sentido, para compreender o desastre socioambiental como processo assim como acontecimento público midiatizado, buscaremos antes situar o contexto da mineração em Barcarena e na Amazônia a partir da discussão com autores da Ecologia Política, bem como, em uma perspectiva decolonial, compreender a mídia como campo social em permanente e desigual disputa discursiva.

\section{Formação de Barcarena como zona de sacrifício e recorrência de desastres}

Desde a colonização e as missões religiosas do século XVII, a área do baixo Tocantins, onde está localizada Barcarena, enfrenta um processo de expulsão e dominação dos povos tradicionais subalternizados e de interferência em seus modos de vida e produção. Segundo Marcel Hazeu ${ }^{11}$, os jesuítas procuraram adaptar a produção indígena, aumentando a derrubada de florestas e as áreas de plantio e direcionando o extrativismo para a exportação, não mais para o autossustento. Os colonos utilizaram trabalho forçado, primeiro de indígenas, depois de africanos, em plantações de produtos como cacau e em engenhos de cana-de-açúcar ${ }^{11}$. Houve ainda exploração predatória de madeira e, principalmente durante a revolta da Cabanagem, exploração de borracha.

Colonos portugueses, religiosos e elites de Belém “(...) se apropriaram das terras sob a forma de sesmarias, tornando esse espaço propriedade deles”, apesar da ocupação histórica “(...) de outros moradores e do uso tradicional dessas terras" ${ }^{\prime 1}$. Muitos indígenas e africanos, fugindo da condição de escravidão, refugiaram-se na floresta e formaram comunidades. Conforme Hazeu ${ }^{11}$, esse contexto de colonização, escravidão e resistência levou à construção de novas identidades, territórios e relações sociais. Até meados do século XX, a população de Barcarena era quase toda rural - mais de $98 \%$ em 1950 -, vivendo do extrativismo e da agricultura familiar nas ribeiras de rios e igarapés ${ }^{12}$. Contudo, outras pressões surgiram a partir dos anos 1970, e delas derivam, de forma direta, os atuais desastres socioambientais - dentre os quais o caso discutido no presente estudo -, que atingem especialmente os grupos vulneráveis historicamente penalizados.

O caminho para a instalação de um Distrito Industrial em Barcarena teve como pontos de partida o II Plano Nacional de Desenvolvimento (II PND) e o Programa Grande Carajás (PGC). Em execução entre 1974 e 1979, durante a ditadura militar, o II PND focava nas indústrias de base, indicando investimentos em insumos básicos, infraestrutura, energia e bens de capital ${ }^{13}$. Lançado em 1980, ainda na ditadura, e extinto em 1991, na Nova República, o PGC buscava promover o desenvolvimento regional da Amazônia oriental e incluía a construção da Usina Hidrelétrica de Tucuruí, a instalação da Albras (Alumínio Brasileiro S.A.) e da Alunorte (Alumina do Norte do Brasil S.A.) em Barcarena, entre outros empreendimentos ${ }^{14}$.

De acordo com Rosane Maia $^{12}$, a partir de 1977, a Companhia de Desenvolvimento Industrial do Estado do Pará (CDI-PA) passou a desapropriar terras das comunidades locais para instalar o complexo de mineração Albras/Alunorte, o porto de Vila do Conde, uma subestação da Eletronorte e a Vila dos Cabanos. Coube, depois, à Companhia de Desenvolvimento de Barcarena (CODEBAR) dar seguimento às desapropriações. Data de 1978 a criação da Albras, produtora de alumínio primário, e da Alunorte, refinaria de alumina, a partir da parceria entre a então estatal Companhia Vale do Rio Doce e o consórcio japonês Nippon Amazon Aluminum Corporation. As empresas só começaram a operar em 1985 (Albras) e 1995 (Alunorte).

A multinacional norueguesa Norsk Hydro passou a ser acionista majoritária do complexo Albras/ Alunorte em 2010, por meio de um acordo de troca de ações com a Vale, àquela altura já privatizada. Além das indústrias do alumínio, uma série de outras empresas se instalou em Barcarena nos últimos 30 anos, como a Imerys Rio Capim Caulim e a Pará Pigmentos (caulim/porto), a Votorantim (cimento), a Usipar (ferro-gusa), a Alubar (alumínio), a Buritirama (manganês), a Bunge (adubo/porto), a Oxbow Brasil 
Energia (coque), a ADM Brasil (agronegócio/porto), a White Martins (gases industriais e medicinais), a TIMAC, a Fertilizantes Tocantins e a Yara Brasil (fertilizante) ${ }^{12}$.

Barcarena, com seu distrito industrial e todo o histórico de expropriação dos povos tradicionais, tornouse uma zona de sacrifício. Para Maristela Svampa e Enrique Viale ${ }^{15}$, zona de sacrifício não diz respeito apenas ao deslocamento de territorialidades subalternizadas pela emergência de uma territorialidade excludente, mas também à degradação dos territórios e da vida por conta de um modelo predatório de desenvolvimento. "Com o passar do tempo, o que resta para as comunidades locais são os impactos ambientais e sociossanitários (...), territórios convertidos em áreas de sacrifício nas quais os corpos e as vidas se tornam descartáveis e dispensáveis" (tradução livre) ${ }^{15}$.

Edna Castro ${ }^{1}$ lembra que, na Amazônia, há uma proliferação de zonas de sacrifício, onde a riqueza e a biodiversidade acabam substituídas pela violência do desmatamento, do lixo tóxico, do adoecimento coletivo, não apenas humano. Esse processo está baseado em uma concepção colonial de dominação sobre a natureza e na privatização do que deveria ser comum. No caso de Barcarena, a ocorrência continuada de desastres socioambientais é uma das expressões mais evidentes da zona de sacrifício cravada ali, que se propaga para além do território, já que a contaminação atinge rios e igarapés que seguem seus cursos. A maioria dos desastres catalogados tem relação com a atividade mineradora.

Quadro 1 - Histórico de desastres socioambientais em Barcarena

(continua)

\begin{tabular}{|c|c|}
\hline Ano & Caso \\
\hline 2000 & $\begin{array}{l}\text { Naufrágio da balsa Miss Rondônia em frente ao porto de Vila do Conde, com derramamento de } \\
\text { aproximadamente } 2 \text { milhões de litros de óleo no rio Pará }\end{array}$ \\
\hline 2002 & $\begin{array}{l}\text { Derramamento de cerca de } 100 \text { quilos de coque no rio Pará por falha no transporte para o complexo } \\
\text { industrial Albras/Alunorte }\end{array}$ \\
\hline \multirow{3}{*}{2003} & $\begin{array}{l}\text { Vazamento de grande proporção de lama vermelha da bacia de rejeitos da Alunorte, com contaminação } \\
\text { do rio Murucupi }\end{array}$ \\
\hline & $\begin{array}{l}\text { Chuva de fuligem em Vila do Conde, que encobriu praias, rios, casas e comércios com material particulado } \\
\text { de coloração preta }\end{array}$ \\
\hline & Estouro de tanque de soda cáustica da Alunorte, causando contaminação do Rio Pará \\
\hline \multirow[t]{2}{*}{2004} & $\begin{array}{l}\text { Vazamento de grande proporção de material proveniente da bacia de rejeitos da Imerys, com } \\
\text { contaminação dos igarapés Curuperé e Dendê }\end{array}$ \\
\hline & Contaminação do meio ambiente, incluindo praias e rios, por fuligem da Alunorte \\
\hline 2005 & Contaminação do rio Pará por soda cáustica da Alunorte \\
\hline \multirow[t]{2}{*}{2006} & $\begin{array}{l}\text { Fenômeno de "floração de algas" no Igarapé Mucuraçá e na Praia do Caripi, sem causa imediata } \\
\text { esclarecida, mas ligado a atividades antrópica/industriais }\end{array}$ \\
\hline & Vazamento de material da bacia de rejeitos da Imerys, com contaminação dos cursos d'água \\
\hline \multirow{2}{*}{2007} & Vazamento envolvendo rejeitos da Imerys, desta vez em maior proporção, atingindo o rio Pará \\
\hline & Mortandade de peixes no rio Arienga, iniciada próximo à área industrial da Cosipar \\
\hline \multirow{3}{*}{2008} & Vazamento de caulim no rio das Cobras e nos igarapés Curuperé, Dendê e São João \\
\hline & Vazamento de óleo das instalações da Petrobras em Vila do Conde \\
\hline & $\begin{array}{l}\text { Naufrágio do rebocador Jeany Glalon XXXII próximo ao furo do arrozal, com vazamento de } \\
\text { aproximadamente } 30 \text { mil litros de óleo }\end{array}$ \\
\hline 2009 & Vazamento de lama vermelha da bacia de rejeitos da Alunorte, atingindo várias comunidades \\
\hline 2010 & Nuvem de fuligem, que encobriu todo o bairro industrial \\
\hline 2011 & Rompimento de duto com efluentes ácidos da Imerys, atingindo os igarapés Curuperé e Dendê \\
\hline 2012 & Vazamento de material da bacia de rejeitos da Imerys, contaminando o rio Maricá \\
\hline
\end{tabular}




\begin{tabular}{|l|l|}
\hline Ano & Caso \\
\hline \multirow{2}{*}{2014} & Vazamento de rejeitos da Imerys, contaminando os igarapés Curuperé e Dendê \\
\cline { 2 - 2 } 2015 & Despejo de soja e fezes de bois no rio Arrozal, na região do porto da Vila do Conde, pela Bunge \\
\hline \multirow{2}{*}{2016} & $\begin{array}{l}\text { Naufrágio do navio Haidar no porto de Vila do Conde, carregado com centenas de bois vivos } \\
\text { urbano }\end{array}$ \\
\cline { 2 - 2 } & $\begin{array}{l}\text { Vazamento de caulim da bacia de rejeitos da Imerys, contaminando o rio das Cobras, os igarapés } \\
\text { Curuperé, Dendê e São João e a praia de Vila do Conde }\end{array}$ \\
\cline { 2 - 2 } 2018 & $\begin{array}{l}\text { Naufrágio do rebocador Ciclope } \\
\text { Vazamento de rejeitos da Hydro Alunorte, seguido da descoberta de tubulação clandestina, desvio de } \\
\text { drenagem e canal antigo que despejava efluentes no rio Pará }\end{array}$ \\
\hline
\end{tabular}

Fontes: baseado em Ministério Público Federal/Ministério Público do Estado do Pará16 e Movimento Barcarena Livre ${ }^{17}$.

Os desastres da mineração não se configuram simplesmente como falhas do processo industrial. Eles são produzidos e reproduzidos por uma série de padrões político-institucionais apontados por Andréa Zhouri18: a escolha de tecnologias ultrapassadas e menos custosas, a não responsabilização das empresas e do Estado pelas vidas em perigo, as falhas na fiscalização e no monitoramento, a adoção de medidas mitigadoras para concessão do licenciamento ambiental, o controle e o lobby político das mineradoras, a limitação da participação social no processo decisório e o subdimensionamento na identificação dos atingidos. A recorrência de desastres da mineração em Barcarena indica como o fenômeno é inerente à produção.

O desastre também não é algo isolado, demarcado no tempo. Ao contrário, tem duração prolongada: começa antes da ocorrência, desde a execução dos padrões geradores, e desdobra-se depois, com consequências duradouras na vida dos seres e do meio ambiente. Mais do que um acontecimento pontual, portanto, trata-se de “(...) um processo que se desencadeia por meio de inúmeros fatores, que não finda, e prolongase no tempo e no espaço, na forma de uma violência lenta"19. No caso de Barcarena, há ainda o caráter cumulativo, que faz com que cada novo desastre passe a se juntar aos efeitos continuados dos outros anteriores.

Esse processo deve ser entendido também à luz do conceito de 'efeito derrame' de Eduardo Gudynas ${ }^{20}$, quando o autor se refere aos extrativismosiv na América do Sul, com seus crescentes e conhecidos impactos locais, sociais e ambientais. Gudynas alerta, porém, que os efeitos não se restringem àquela localidade, são mais amplos, afetam a estrutura, a dinâmica e a institucionalidade de estratégias de desenvolvimento, das políticas setoriais, como a econômica ou comercial e inclusive, o que é subjetivamente contundente, os modos de entender a natureza, a justiça e a democracia ${ }^{20}$.

Há, nesse sentido, um desdobramento de efeitos interconectados que se espraiam para além do local, no espaço e também no tempo. A flexibilização ambiental - de regras de fiscalização do funcionamento de usinas ou de uso e acesso a territórios pela mineração, por exemplo, a partir de lobbys e bancadas parlamentares - gera ao longo do tempo uma violação ampliada de direitos sociais e da natureza, muitas vezes justificada por argumentos que priorizam o econômico sobre todos os demais fatores. Embora o extrativismo se dê em um dado território local, responde a um palco global de interesses econômicos, reforçando estratégias de desenvolvimento de base capitalista, que findam por manter os países sul-americanos subordinados

iv A compreensão do conceito de 'extrativismo' para o autor é essencial para entendermos o alcance e a dimensão do alerta

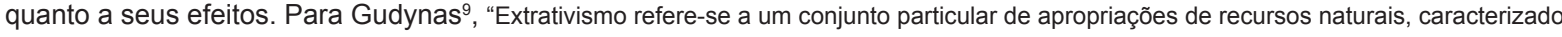
por grandes volumes removidos e / ou alta intensidade, onde metade ou mais é exportada como matéria-prima, sem processamento industrial ou processamento limitado. Portanto, de acordo com essa definição, os extrativismos são plurais, incluindo empreendimentos como mega-mineração a céu aberto, pequena mineração aluvial de ouro (legal ou ilegal), exploração de petróleo ou gás natural ou várias monoculturas para exportação, onde o caso mais proeminente é a soja." 
dentro da globalização como provedores de matérias-primas - seja pela exploração de minério seja pelo agronegócio.

A cobertura midiática no Brasil tende a não acompanhar os 'efeitos derrame' dos desastres ambientais. Se, por um lado, a partir dos anos 1990, ampliou-se o interesse pelo tema - com pautas ambientais como o impacto das mudanças climáticas e, em especial, as grandes tragédias, os casos de Mariana, Brumadinho e Barcarena - por outro lado, especialmente os meios da chamada grande imprensa, com seus modos de produção da notícia atrelados a molduras comerciais de rotinas, fluxos, prazos ou linha editorial, permanecem limitados ou impedidos de perceber ou acompanhar os efeitos ampliados, as causas e os desdobramentos dos desastres. O resultado, conforme Wilson Bueno ${ }^{21}$, é uma cobertura jornalística concentrada no tempo, descontextualizada, imprecisa e fragmentada. "No caso brasileiro, a inexistência de profissionais capacitados para esta cobertura em milhares de veículos distribuídos por todo o território nacional, o lobby poderoso desencadeado por interesses empresariais que impactam o meio ambiente (agroquímicas, mineradoras, empresas de biotecnologia, setores conservadores do agronegócio etc.), dentre outras razões, têm contribuído para uma cobertura fragmentada, descontextualizada e imprecisa da problemática ambiental”21.

Mais do que o foco em jornalistas, em veículos da imprensa isoladamente, regionais ou nacionais, é importante considerar que aos processos de produção jornalística e consequentemente aos critérios de noticiabilidade vigentes ${ }^{22}$ - sejam dos atributos primários utilizados na seleção do fato, na sua interpretação ou mesmo na visão epistemológica e ética sobre o acontecimento - é central não perder de vista, como aponta Lannes Rocha ${ }^{23}$, que o sistema midiático atua de forma indissociável dos sistemas econômico e político. Significa dizer, conforme o autor, que "Como expressão da hegemonia de seu tempo, que a constitui em sua essência técnica e ideológica, a mídia é fundamentalmente a expressão do mercado e do capital”. Certamente há brechas na produção de sentidos, mas mesmo quando a crítica socioambiental se impõe, como em casos de desastres, percebe-se uma dificuldade de conectar o crime local com a rede global que o possibilita.

Grandes setores da economia, como o da mineração, do agronegócio - setores ligados a commodities e ao capital internacional -, da construção civil assim como o setor de energia, com as grandes obras e empreiteiras, sustentam relações imbricadas, históricas e difusas entre mídia e poder político no país. Políticos que fazem lobby em defesa desses setores, contrariando a Constituição, também representam ou integram muitas vezes grupos familiares vinculados a meios diversos de comunicação ${ }^{24}$, em um quadro de concentração midiática que agrava as assimetrias entre os atores sociais envolvidos na disputa por visibilidade de suas causas e interesses. Essa é uma realidade que envolve o cenário midiático nacional e, pode-se dizer, de forma agravada, regionalmente, em especial os estados onde as riquezas naturais são fatores permanentes de geração de conflitos e danos socioambientais.

\section{O caso do desastre da Hydro Alunorte de 2018}

De acordo com o Ministério de Indústria, Comércio Exterior e Serviços ${ }^{25}$, a extração de minérios e a produção minero-metalúrgica teve um crescimento extraordinário no Brasil entre 2000 e 2017, com incremento de 620,9\% em toneladas por ano. Essa intensificação promoveu a multiplicação de barragens e, consequentemente, de vazamentos e rompimentos de reservatórios de resíduos, sendo os mais notórios o da empresa Samarco Mineração S.A., em novembro de 2015, no município de Mariana, em Minas Gerais, e o da Vale S.A., em janeiro de 2019, no município de Brumadinho, no mesmo estado.

Só no Pará, entre 2007 e 2017, o porto de Vila do Conde, em Barcarena, registrou aumento de 42\% na exportação de alumínio e alumina, saindo de 3.674.441 toneladas para 5.223.349 toneladas do minério, sendo parte desse fluxo de responsabilidade da Hydro Alunorte, que possui duas barragens de rejeitos: DRS1 e DRS2. De acordo com Jondison Rodrigues, Marcel Hazeu e Sabrina Nascimento ${ }^{26}$, a empresa se recusa a utilizar o termo barragem, classificando-as em discursos e no processo de licenciamento ambiental 
como Depósito de Resíduos Sólidos (DRS) - por essa razão, não figuram na listagem de barragens da Associação Nacional do Minério (ANM).

No dia 17 de fevereiro de 2018, um sábado, ainda sob os ecos da tragédia em Mariana, os moradores de Barcarena denunciaram ao Ministério Público do Estado do Pará (MPPA) aquele que viria a ser um dos crimes ambientais de maior repercussão entre os tantos já registrados no município. A população local se viu naquela manhã chuvosa diante do transbordo do DRS1. O desastre teria sido provocado por um estresse na estrutura em razão da intensa produção mineral e pela precipitação pluviométrica em índices registrados acima da média para o período, que chegou a $173 \mathrm{~mm}$ em apenas 12 horas, fazendo com que material tóxico fosse despejado na bacia do Rio Pará e seus afluentes, contaminando águas e atingindo as comunidades locais.

Para entender o prolongamento do desastre, apresentamos a seguir, de forma sintética, um conjunto de desdobramentos que marcam os oito meses considerados no primeiro momento de análise deste estudo e seguem adiante - desde o fato gerador, o transbordamento dos rejeitos e a denúncia pela comunidade local, em fevereiro, até o início de outubro, quando a empresa retoma sua produção integral, mesmo sem uma solução efetiva para os efeitos sociais ocasionados pelo desastre.

Assim que foi feita a denúncia do possível extravasamento de resíduos pelas comunidades locais, o MPPA realizou a primeira inspeção na área e o Instituto Evandro Chagas (IEC), órgão vinculado à Secretaria de Vigilância em Saúde do Ministério da Saúde, fez a avaliação de danos ambientais e riscos à saúde humana, que confirmou a contaminação. Houve em seguida protestos populares, criação de força-tarefa reunindo os Ministérios Públicos Federal e do Estado, além da notificação da Hydro e da Secretaria de Estado de Meio Ambiente e Sustentabilidade do Pará (SEMAS), com uma série de recomendações, incluindo o embargo de uma das bacias de rejeitos da refinaria. A denúncia também provocou a abertura de duas investigações sobre o caso, em uma delas a Justiça estadual obrigou a empresa a reduzir a produção pela metade.

Além do vazamento inicial, outras irregularidades foram identificadas na empresa no decorrer de vistorias e investigações: a existência de uma tubulação clandestina, que lançava material contaminado no meio ambiente; de um canal antigo, de onde saíam efluentes não tratados; e de um desvio de drenagem de água da chuva do galpão de carvão. Apesar das evidências, a Hydro mobilizou recursos jurídicos e técnicos para negar o transbordamento, contestar laudos e postergar o atendimento das obrigações legais.

Em 22 de março, ocorreu a primeira audiência pública em Barcarena - houve mais uma ainda em 2018 e outras duas em 2019. No dia seguinte, a força-tarefa apresentou à Hydro proposta de Termo de Compromisso de Ajustamento de Conduta (TAC) para ações emergenciais, que previa atendimento às comunidades, garantia da segurança das barragens, do processo produtivo e da qualidade dos planos de emergência da empresa.

Em abril, a Hydro manifestou discordância com os relatórios do IEC, sob a alegação de que o Instituto não possuía acreditação válida para realizar amostragens e análises, resposta interpretada como recusa à assinatura do termo de ajuste de conduta. A empresa ofereceu contraproposta sobre ações emergenciais no dia 25 de abril, ainda assim, moradores denunciaram interrupção do fornecimento de água potável pela Hydro, o que provocou a Justiça Federal a publicar decisão liminar determinando a suspensão parcial das atividades da mineradora e a proibição do uso do DRS2.

O TAC para o governo do Pará e a Hydro só foi assinado em 5 de setembro de 2018. Em outubro, a empresa anunciou a suspensão de suas operações. Naquele mesmo mês, o Instituto Brasileiro do Meio Ambiente e dos Recursos Naturais Renováveis (Ibama) autorizou o uso de nova tecnologia para processamento de resíduos de bauxita pela Hydro e a retomada da produção em 50\%. Ainda em 2018, a Comissão externa da Câmara dos Deputados publicou relatório de investigação sobre o caso.

Do dia em que os veículos de comunicação começaram a publicar conteúdos, 19 de fevereiro, até o dia 19 de outubro, data em que se encerra o levantamento, passaram-se cerca de 8 meses ou mais precisamente 
243 dias. Durante todo esse tempo, a população manifestou sua insatisfação e a cobrança por providências em protestos na cidade de Barcarena, em frente à sede da empresa. Após o período da amostragem, quando completou dois anos do caso, houve o mais recente protesto, com o fechamento da rua em frente a um dos prédios-sede do Ministério Público Federal em Belém.

\section{O desastre da Hydro em Barcarena: a cobertura Midiática em número e vozes}

\section{Fluxos e frequências da cobertura midiática}

A primeira etapa da metodologia de coleta e análise dos dados teve como objetivo aferir a quantidade de publicações jornalísticas e a multiplicidade de veículos de comunicação, inclusive da imprensa nacional, que deram visibilidade ao desastre da Hydro e seus desdobramentos. Verificou-se, assim, a dimensão da relevância do caso, constatada em análise quantitativa, considerando o período de 19 de fevereiro a 19 de outubro de 2018 por meio da busca pela palavra 'Barcarena' na ferramenta de clipping digital cedida pela assessoria de comunicação do Ministério Público do Estado do Pará. Com isso, seria possível mensurar a quantidade de publicações relacionadas, dividir por meses, calcular a média de publicações diárias em cada mês, classificar por meio de comunicação, veículo e ordenar por ordem de publicação quem mais tratou do assunto.

O assunto ganhou espaço na mídia dois dias depois do desastre e da denúncia dos moradores, no dia 19 de fevereiro, quando a imprensa publicou com destaque as primeiras notícias a respeito do crime socioambiental que se configurava, alcançando repercussão na mídia nacional. Nos 243 dias de análise, de 19 de fevereiro até 19 de outubro de 2018, foram contabilizadas 1.322 publicações em 74 veículos, sendo 28 sites jornalísticos/portais de notícias, 16 emissoras de TV, 10 blogs jornalísticos, 10 jornais impressos e 10 emissoras de rádio. A tabela abaixo apresenta a frequência das publicações a cada mês.

Tabela 1 - Totalização dos dados sobre o número de notícias sobre o desastre da Hydro em Barcarena

\begin{tabular}{cccccccccccc} 
& Fevereiro & Março & Abril & Maio & Junho & Julho & Agosto & Setembro & Outubro & Total \\
Jornal & 75 & 184 & 99 & 52 & 44 & 20 & 19 & 12 & 20 & $\mathbf{5 2 5}$ \\
Site & 74 & 98 & 49 & 37 & 20 & 18 & 23 & 3 & 26 & $\mathbf{3 4 8}$ \\
TV & 79 & 96 & 43 & 15 & 12 & 6 & 3 & 6 & 5 & $\mathbf{2 6 5}$ \\
Blog & 24 & 48 & 23 & 6 & 7 & 7 & 6 & 0 & 8 & $\mathbf{1 2 9}$ \\
Rádio & 16 & 14 & 10 & 4 & 5 & 1 & 5 & 0 & 0 & $\mathbf{5 5}$ \\
Total & $\mathbf{2 6 8}$ & $\mathbf{4 4 0}$ & $\mathbf{2 2 4}$ & $\mathbf{1 1 4}$ & $\mathbf{8 8}$ & $\mathbf{5 2}$ & $\mathbf{5 6}$ & $\mathbf{2 1}$ & $\mathbf{5 9}$ & $\mathbf{1 3 2 2}$ \\
Dias & 10 & 31 & 30 & 31 & 30 & 31 & 31 & 30 & 19 & $\mathbf{2 4 3}$ \\
Média & 26,80 & 14,19 & 7,47 & 3,68 & 2,93 & 1,68 & 1,81 & 0,70 & 3,11 & $\mathbf{5 , 4 4}$ \\
\hline
\end{tabular}

Fonte: Os autores (2019).

É interessante observar, na última linha da tabela acima (Tabela 2), a média diária de notícias em cada mês, o que nos fornece parâmetros mais precisos acerca da evolução proporcional da cobertura, que iniciou intensa nos primeiros dias e foi perdendo volume com o passar do tempo. Com a finalidade de acentuar essa constatação, traçamos um gráfico com a quantidade média das notícias publicadas pelo número de dias observados em cada mês, o que permitiu visualizar, de fevereiro a abril, um arco de publicações superior à média total, e o início da tendência decrescente já a partir do mês seguinte. 
Na figura é possível visualizar a diluição, com o passar do tempo, do interesse da mídia pelo assunto que coincide com a diminuição de eventos midiatizados acerca do desastre. A projeção mostra uma queda que se acentua a partir de junho e, apesar de ligeiro crescimento, a tendência é a estabilização abaixo da média.

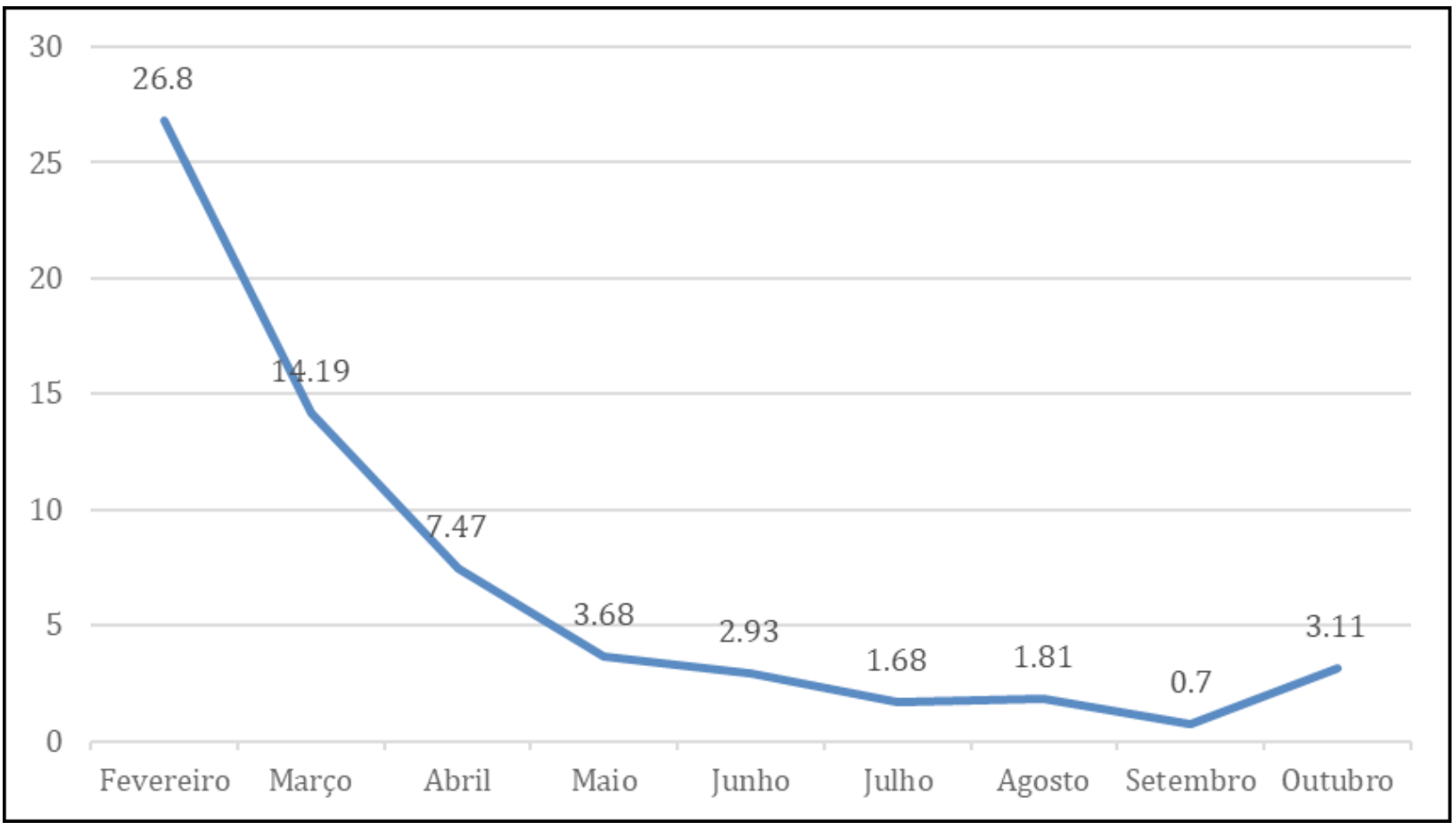

Figura 1 - Evolução da média de notícias publicadas por mês no período de 19 fev. a 19 out. 2018 Fonte: Os autores (2019).

No recorte da quantidade de publicações por mídia (Figura 2), há um predomínio constante dos jornais impressos como os mais relevantes do início ao fim. Emissoras de TV e sites de jornalismo concorriam nos primeiros meses com números bem próximos, sendo que as reportagens televisivas expandiram a discussão em âmbito nacional, enquanto os sites e os blogs - que somados colocam as publicações online em segundo lugar nessa lista - deram permanência aos textos na internet, podendo ser acessados até hoje pela própria característica de memória na internet.

Ao final do período, podemos ver a tendência no ganho de protagonismo da internet como a mídia mais ativa na amostragem. Por outro lado, houve menos evidências de conteúdos radiofônicos. Ainda que possamos levar em conta as limitações da ferramenta de clipping como uma das hipóteses para a cobertura rarefeita dos noticiários de rádio, surpreende negativamente a falta de protagonismo da mídia sonora, considerando a tradição do veículo na Amazônia. 


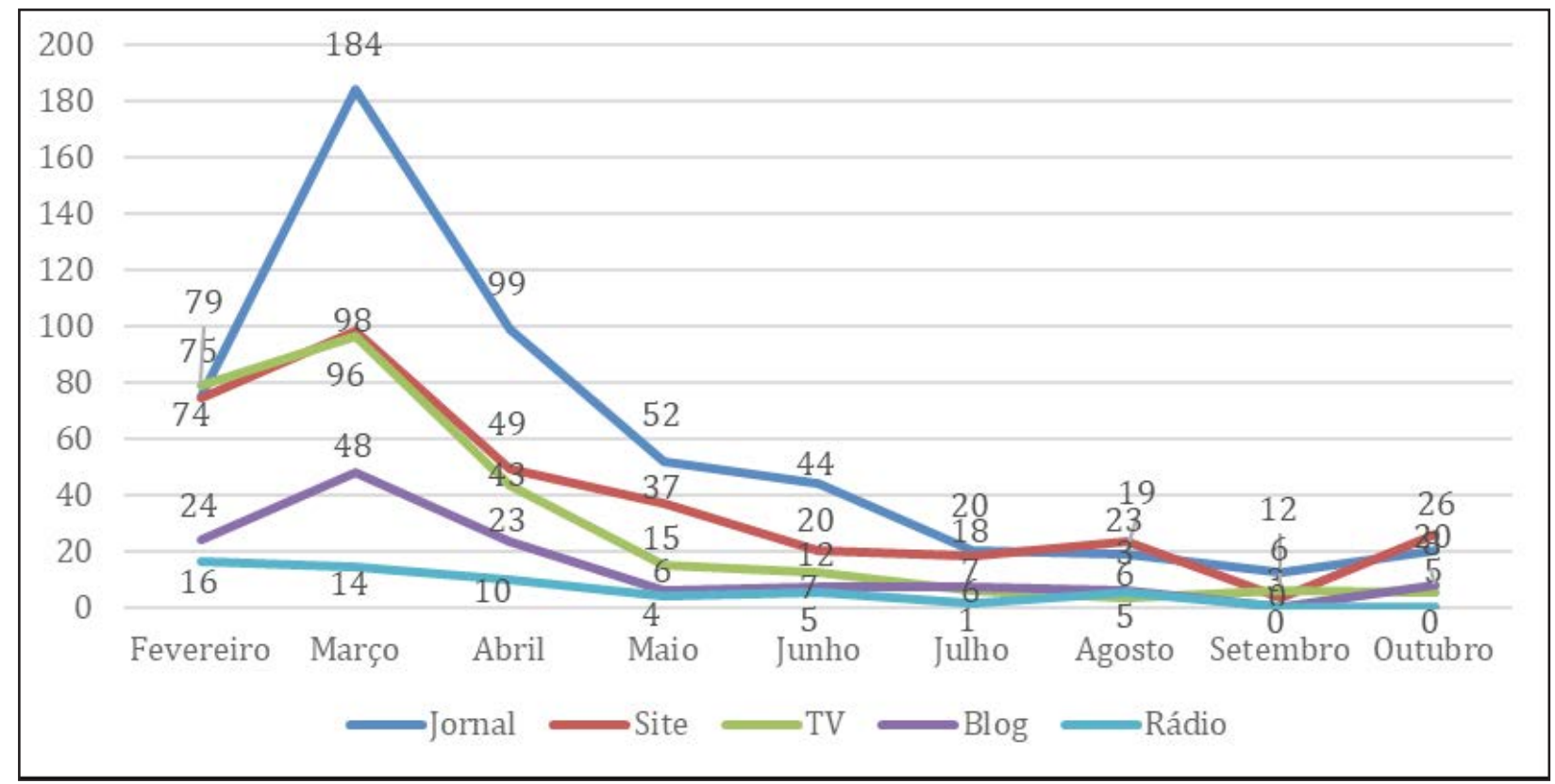

Figura 2 - Evolução mensal da cobertura jornalística do desastre por mídia de 19 fev. a 19 out. 2018 Fonte: Os autores (2019).

Foram identificados na análise das publicações 74 veículos de comunicação, sendo 28 sites e 16 emissoras de TV. Blogs, rádios e jornais impressos contribuíram com 10 veículos cada. No entanto, apesar da quantidade menor de jornais que participaram da cobertura, eles respondem por 40\% do total de notícias veiculadas no período. Sites aparecem logo depois, com $26 \%$ e, somados com 10\% dos blogs, fazem com que a internet contribua com $36 \%$ das publicações. As TVs representam um quinto do material, e o rádio participa em apenas $4 \%$, conforme a figura abaixo (Figura 3).

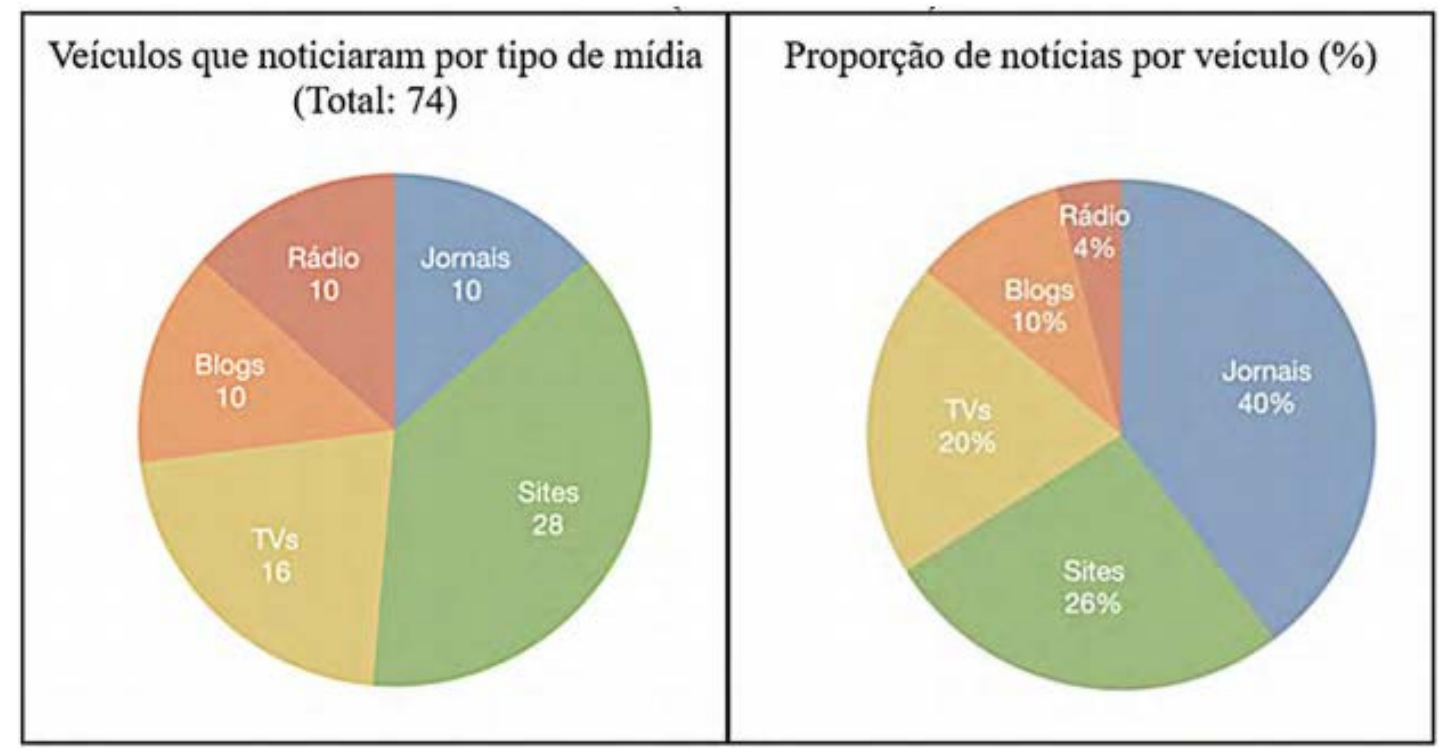

Figura 3 - Relação entre veículos noticiosos e o total de notícias veiculadas de fev. a out. 2018 Fonte: Os autores (2019).

Dos 20 veículos que mais participaram da cobertura jornalística durante os oito meses analisados, a TV é a que aparece com o maior número de emissoras na cobertura (6), logo depois vêm os sites ou portais de notícia (5), blogs (4), jornais (4) e apenas uma rádio (1). Entretanto, são os jornais os veículos com maior regularidade em todo o período considerado, conforme explicitado na tabela a seguir (Tabela 3). 
Os jornais impressos regionais/locais O Liberal e Diário do Pará foram os meios com maior regularidade, seguidos por G1 Pará e Diário do Pará Online, representando os sites ou portais jornalísticos. TV Liberal e TV Record Pará surgem na sexta e sétima posição, como as principais na sua modalidade de mídia. O primeiro blog, Ver-o-Fato, de caráter local, aparece em oitavo lugar. Só no décimo quarto lugar surge a primeira rádio da amostragem, a Rádio Clube do Pará.

Tabela 3-Os 20 veículos que mais publicaram sobre o assunto de fev. a out. 2018

\begin{tabular}{|c|c|c|c|}
\hline Tipo & Procedência & Veículo & Quantidade \\
\hline Jornal & Pará & O LIBERAL - PA & 217 \\
\hline Jornal & Pará & DIÁRIO DO PARÁ - PA & 211 \\
\hline Site & Pará & G1 - PARÁ & 105 \\
\hline Site & Pará & DIÁRIO DO PARÁ - ON LINE & 98 \\
\hline Jornal & Pará & AMAZÔNIA JORNAL - PA & 69 \\
\hline Televisão & Pará & TV LIBERAL / AF. GLOBO - PA & 67 \\
\hline Televisão & Pará & TV RECORD - PA & 61 \\
\hline Blog & Pará & BLOG VER-O-FATO - PA & 48 \\
\hline Televisão & Pará & TV RBA - BAND - BELÉM & 38 \\
\hline Blog & Pará & BLOG DO BACANA - PA & 21 \\
\hline Blog & Pará & BLOG DO LÚCIO FLÁVIO PINTO - PA & 21 \\
\hline Site & Pará & FOLHA DO PROGRESSO - PA & 21 \\
\hline Televisão & Nacional & TV GLOBO - NACIONAL & 20 \\
\hline Rádio & Pará & RÁDIO CLUBE MARABÁ AM 770 - PA & 20 \\
\hline Televisão & Pará & TV SBT - PA & 20 \\
\hline Blog & Pará & BLOG DA FRANSSINETE FLORENZANO - PA & 19 \\
\hline Site & Pará & O IMPACTO ONLINE - PA & 19 \\
\hline Jornal & Pará & JORNAL CORREIO CARAJÁS - PA & 16 \\
\hline Televisão & Nacional & GLOBO NEWS & 15 \\
\hline Site & Nacional & UOL - SP & 13 \\
\hline
\end{tabular}

Fonte: Os autores (2019).

A TV Globo Nacional aparece na metade inferior da tabela em número total de publicações no período considerado, sendo o meio mais constante de cobertura nacional, acompanhada apenas pela Globo News, que faz parte do mesmo conglomerado de mídia, e pelo site da UOL, ambos no fim da lista. A repercussão dada por TV Globo e Globo News certamente é facilitada por contarem com estrutura e produção da emissora afiliada local. Mas o ponto principal que o levantamento indica é a aparição minguada do desastre de Barcarena na mídia nacional.

Esse dado ilustra a desproporcionalidade entre os relatos jornalísticos produzidos para consumo regional e aquele dedicado à audiência nacional. Nesse segundo caso, foi observado que as matérias se 
concentram no início da cobertura, especialmente ampliando a abrangência nos primeiros meses, todavia sem o devido aprofundamento das questões. Isso pode ser explicado sob o prisma do que Nelson Traquina ${ }^{6}$ observa nas rotinas jornalísticas, como a predominância do que Gurevith e Blumbler chamam de 'centro', entendido como o local onde as notícias são construídas, perante a 'periferia', que pode ser definida como o local onde os 'atores políticos' da narrativa atuam.

Considerando que as notícias são 'empacotadas' no Rio de Janeiro e em São Paulo, onde se situam as sedes respectivamente das organizações Globo e da UOL, é perceptível que buscam atender demandas informacionais do 'centro', no caso a região Sudeste, reduzindo o papel do repórter, que tem sua cobertura orientada por instruções que observam o Norte como o lugar do outro, historicamente associado ao exótico e desconhecido. As desigualdades regionais tomam forma nas hierarquias de visibilidade cristalizadas na reprodução de valores-notícia. Por outro lado, em razão dos critérios de noticiabilidade na seleção dos fatos e da escassez de tempo que afeta suas próprias rotinas, a produção da informação tende a se concentrar em algumas poucas fontes, que possuem, por sua vez, estratégias de promoção de esforços para 'gerir' as notícias.

\section{O desastre por suas fontes: a presença reduzida de vozes populares na mídia}

Em que parcela da cobertura midiática as vozes populares foram ouvidas? Para responder a essa pergunta, em uma segunda etapa da análise da cobertura midiática do desastre da Hydro Alunorte em Barcarena, o foco passou a ser especificamente a presença/ausência de comunidades atingidas e movimentos sociais/associações comunitárias na cobertura. A partir dos mesmos dados utilizados na etapa panorâmica inicial, seguiram-se dois momentos de recorte temporal: uma análise quantitativa dos quatro primeiros meses da coleta, de fevereiro a maio, e, em uma perspectiva de maior aproximação para aprimorar a verificação qualitativa dos resultados, detalhou-se a cobertura de um único dia, 23 de fevereiro, o de maior frequência de notícias publicadas sobre o acontecimento, com um total de 53 publicações.

A partir da seleção dos registros em que comunidades e movimentos/associações atuaram como fontes, foram contabilizados e identificados quais movimentos tiveram declarações ou informações de seus integrantes citadas, além do sexo tanto de quem fala pelos movimentos quanto de quem fala como cidadão, sem ter designado algum vínculo associativo. A diferenciação dos atores populares ouvidos em (1) comunidade e (2) movimentos sociais/associações comunitárias pareceu necessária por conta da natureza distinta da fala de um morador da comunidade, que tende a ter caráter individual, e da fala de um representante de movimento social, que em geral assume caráter coletivo.

Do total de 1.042 registros de material nos meses de fevereiro, março, abril e maio de 2018, pouco mais de um quarto (26\%) trouxe declarações ou tem comunidades e movimentos como fontes. Cerca de $74 \%$ da cobertura, portanto, não deram ouvidos às vozes populares - ao menos não diretamente. 


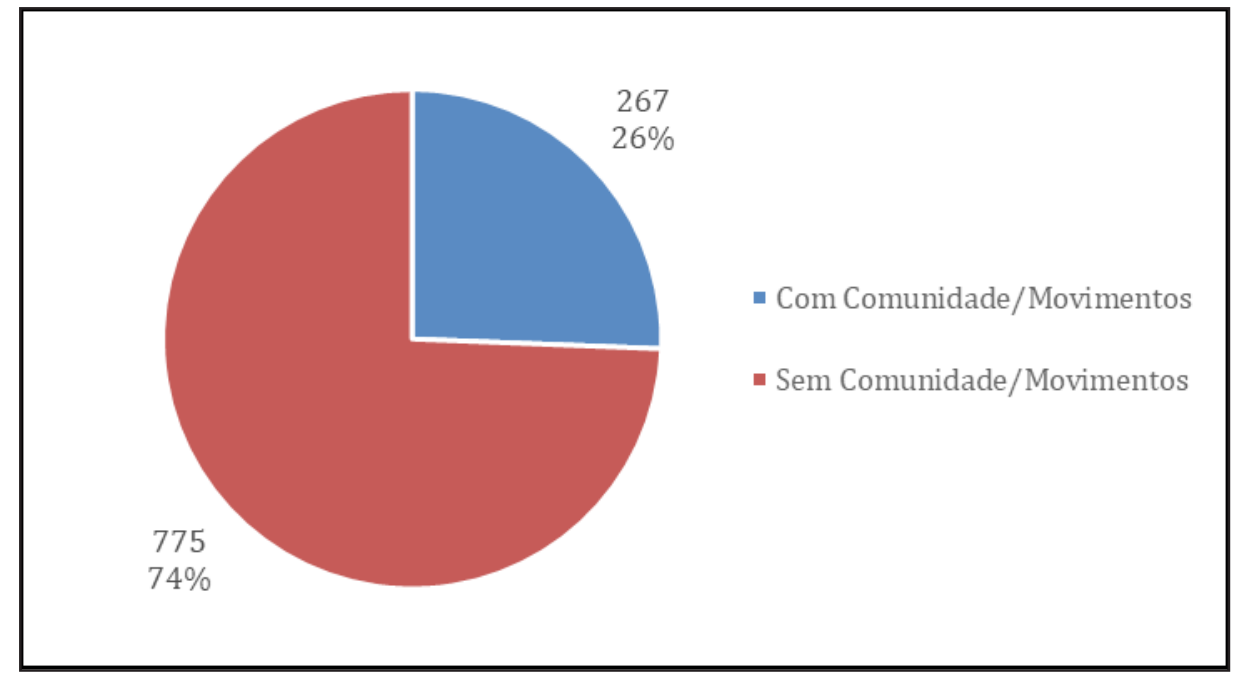

Figura 4 - Espaço ocupado na cobertura da mídia por comunidades e movimentos Fonte: Os autores (2019).

Dos 267 registros identificados com espaço para comunidades e movimentos/associações, mais de 90\% tiveram alcance local. Apenas 10\% dessa cobertura foram feitos por veículos nacionais. A repercussão das falas dos grupos e das populações atingidos, na maioria dos casos, ficou restrita ao estado do Pará.

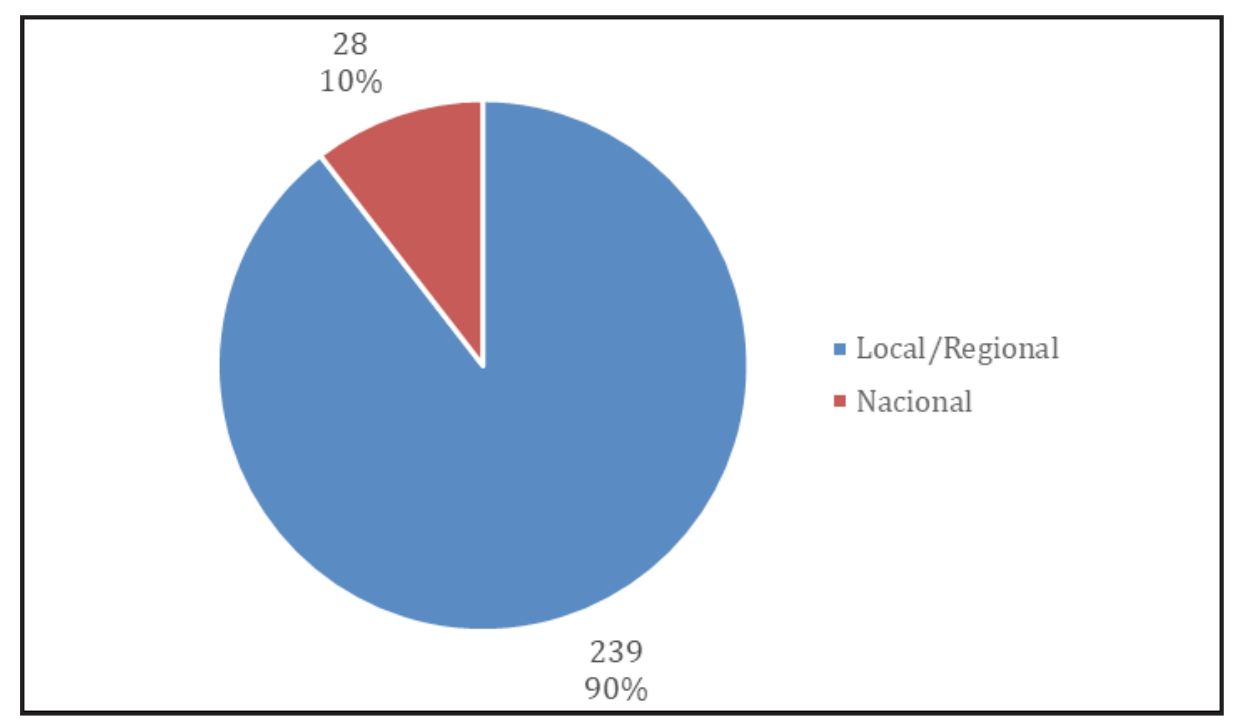

Figura 5 - Alcance da cobertura da mídia com a presença de vozes populares Fonte: Os autores (2019).

A Associação dos Caboclos, Indígenas e Quilombolas da Amazônia (Cainquiama) foi o movimento que mais ocupou espaço na mídia, seguido pelas categorias não especificadas 'advogado socioambiental/ das comunidades, líder ou representante comunitário' e pelo Sindicato dos Químicos de Barcarena (SindQuímicos). Entidades importantes, como o Movimento Barcarena Livre, quase não aparecem na cobertura. 


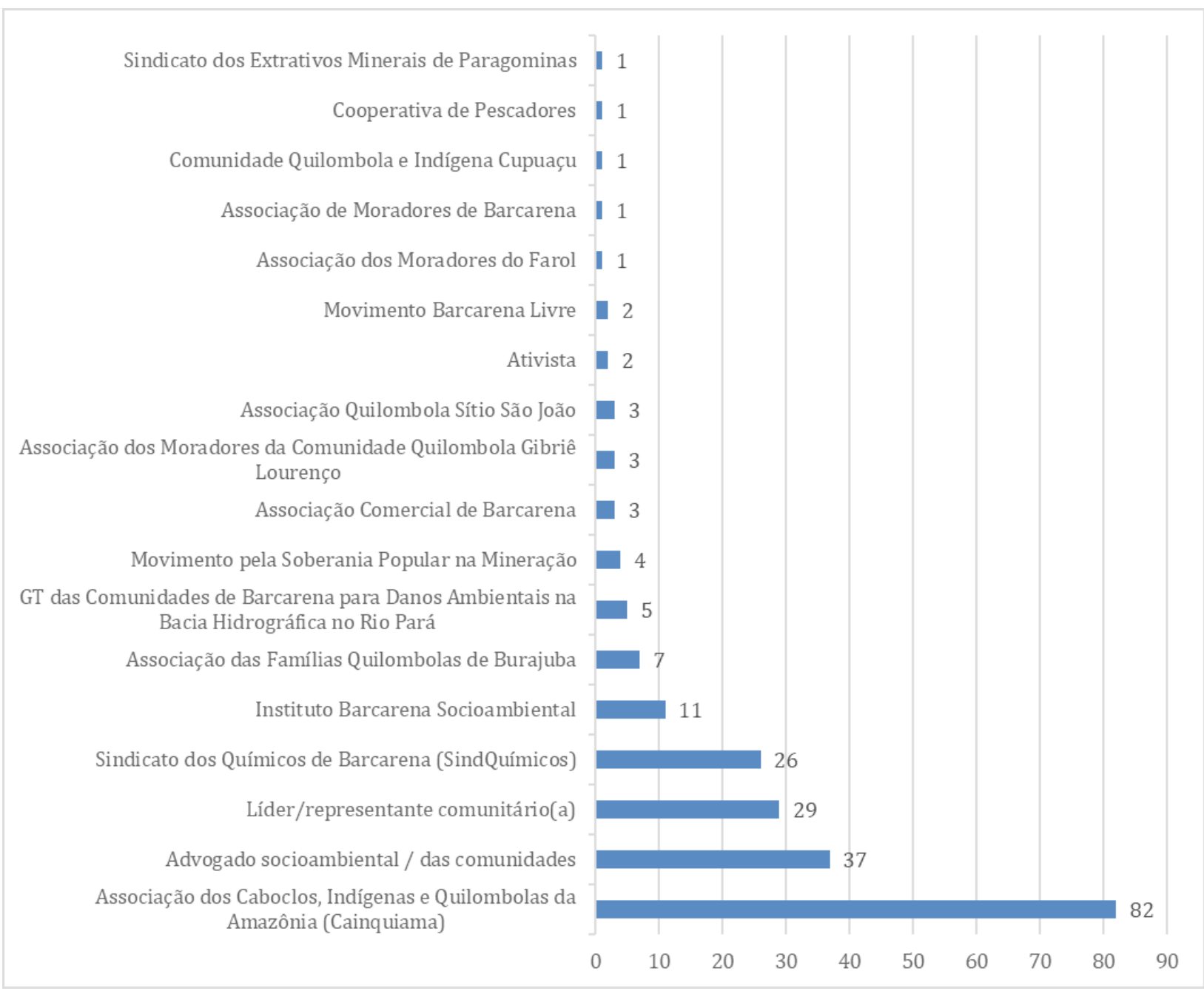

Figura 6 - Movimentos sociais e representações comunitárias na mídia Fonte: Os autores (2019).

A fonte mais frequente na mídia dentre as vinculadas aos movimentos foi Ismael Moraes, citado ora como ligado à Cainquiama, ora como advogado das comunidades ou advogado socioambiental. Ocorre que Moraes não é uma liderança local orgânica, mas um quadro de apoio nas lutas. Sua profissionalização como fonte, a facilidade de acesso, além das proximidades geográfica e cultural com as redações de Belém - cidade onde atua profissionalmente - são hipóteses de porque o advogado tornou-se mediador entre o mundo das comunidades e o mundo midiático.

As mulheres foram maioria entre os cidadãos das comunidades que falam como moradores afetados (63\%), mas não ganharam tanto espaço como integrantes das entidades locais de luta, embora muitas atuem como lideranças. Declarações representando movimentos/associações foram majoritariamente feitas por homens (78\%). 


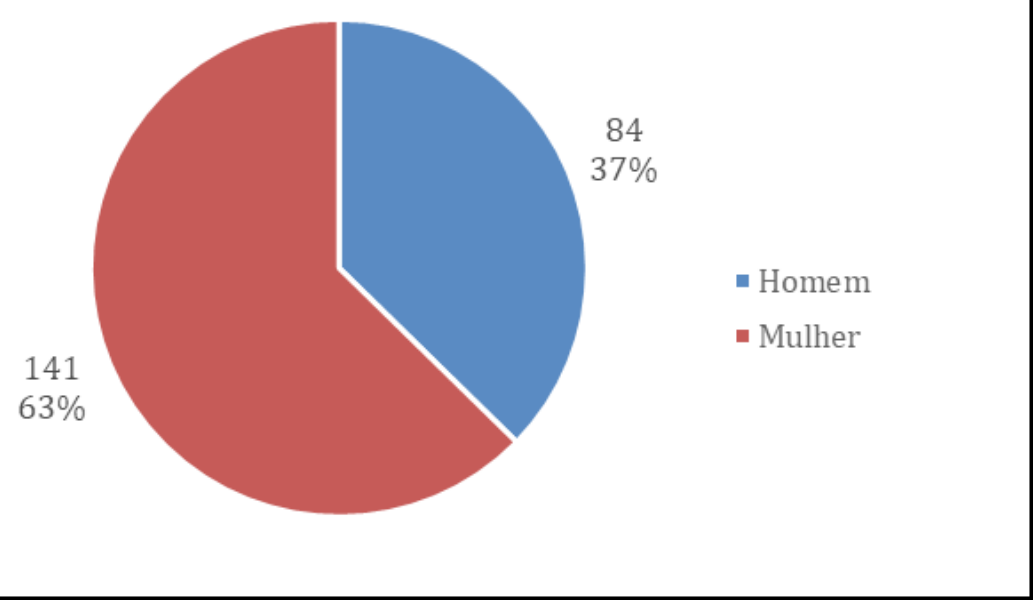

Figura 7 - Sexo de pessoas das comunidades, sem vínculo associativo explícito, ouvidas pela mídia Fonte: Os autores (2019).

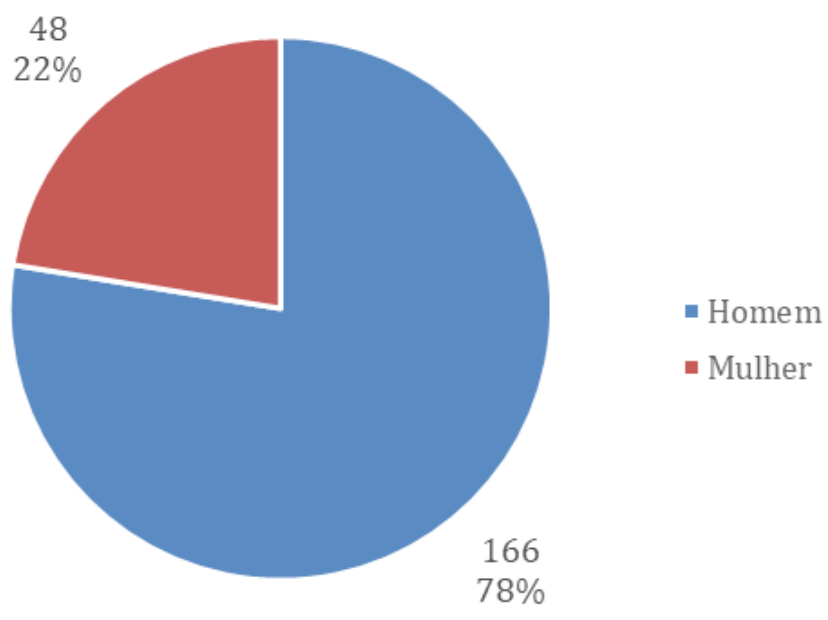

Figura 8 - Sexo de representantes de movimentos/associações ouvidos pela mídia Fonte: Os autores (2019).

A presença reduzida tanto de moradores das comunidades como de representantes de movimentos sociais e associações comunitárias na cobertura do desastre sugere que a mídia concede visibilidade restrita a esses grupos sociais, o que pode reiterar lógicas de racismo ambiental. Quando falaram, as vozes populares reverberaram basicamente no âmbito local/regional. Assim, além do problema de assiduidade, essas fontes enfrentam também um problema de alcance.

Em um contexto em que muitas mulheres integram e até mesmo lideram associações locais, o domínio dos homens nas falas que representam movimentos/associações indica o papel da força patriarcal. Enquanto a fala política de representação coletiva é concentrada nas vozes masculinas, às mulheres é concedida a fala da vivência pessoal, como moradoras atingidas.

O direcionamento hierarquizado da escuta midiática, atravessado como é por marcadores coloniais, acaba por não fortalecer as territorialidades de resistência, espacializando a contenda a respeito do desastre em instâncias institucionais desvinculadas do território onde o crime socioambiental se processa. 


\section{O dia 23 - a cobertura midiática com lupa}

Na tarde do dia 22 de fevereiro, uma quinta-feira, e na manhã do dia 23, sexta-feira, quinto dia a partir do transbordo na bacia de rejeitos da Hydro Alunorte, em Barcarena, um conjunto de ações proativas de atores institucionais, na forma de entrevistas coletivas ou ações de divulgação dirigidas à imprensa, provocaram desdobramentos do acontecimento inicial que resultaram em grande cobertura e publicização do assunto pelos veículos de imprensa, com repercussão nacional e internacional.

Por trazer relatos de fatos cruciais aos desdobramentos do desastre como acontecimento midiático, a análise do dia 23 de fevereiro, com a mais intensa frequência noticiosa sobre o desastre da Hydro em Barcarena $^{v}$, propicia identificar em maior profundidade os elementos propostos nas perguntas iniciais do estudo: quanto se falou e quem falou (meios) sobre o acontecimento e seus desdobramentos (volume da cobertura e alcance dos meios noticiosos - local/regional e nacional), interessando especialmente entender quais as vozes acionadas pela imprensa (fontes) para construir sua narrativa e qual o tratamento/espaço ocupado por elas.

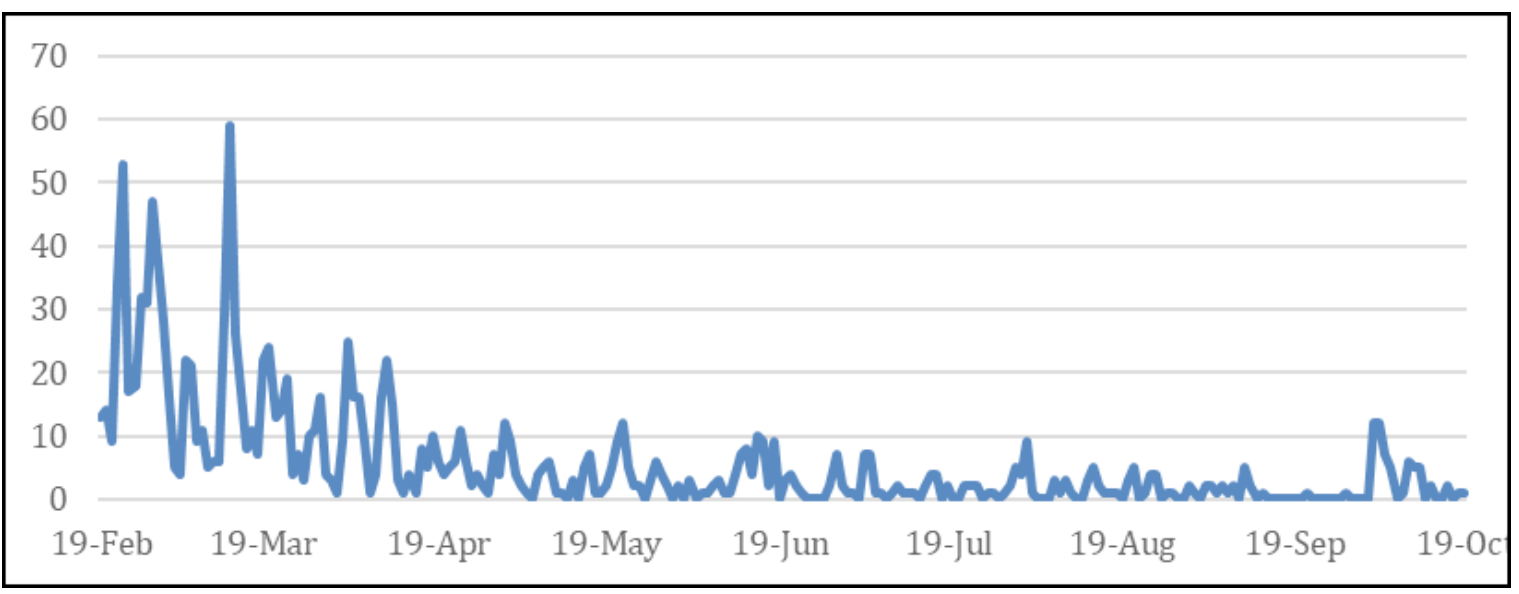

Figura 9 - Frequência diária de publicações acerca do desastre da Hydro em Barcarena (Fev.-Out. 2018) Fonte: Os autores (2019).

No dia 23, primeiro pico da figura acima, os noticiários da TV local foram responsáveis pela maior cobertura jornalística, assim como pelo maior alcance da repercussão dos fatos geradores. Com 85 minutos de notícias, entrevistas e reportagens, em um total de 18 veiculações sobre o assunto ao longo do dia, nos noticiários da manhã, de meio-dia e da noite, as TVs responderam por cerca de 35\% da cobertura geral e por $60 \%$ do noticiário nacional sobre o desastre e seus desdobramentos nesse dia.

Em todos os veículos a cobertura foi basicamente factual, ou seja, com relatos dos acontecimentos por meio de notícias sem maior aprofundamento ou interpretação dos fatos. A opinião, ainda que sem densidade ou crítica, ficou por conta dos apresentadores de programas de jornalismo televisivo popular/policial.

Foi nos jornais e nos portais de notícia, que muitas vezes apenas repetiam o mesmo material do impresso, que a cobertura foi mais diversificada. Ali também aparece o território social do conflito ambiental vivido em Barcarena e consequentemente a disputa discursiva, ainda que assimétrica, sobre o desastre. Começaram a ser nominados as pessoas e o 'lugar' - Rio Murucupi, Vila Nova, Bom Futuro Burajuba - e uns poucos atores coletivos (associações/entidades)

v No dia 13 de março de 2018, o clipping utilizado para a coleta dos dados da cobertura chegou a registrar 59 publicações, porém parte delas sem uma associação direta comprovada com o acontecimento em foco. Um terço das notícias daquele dia dizia respeito ao assassinato de uma liderança social do município de Barcarena. Nesse sentido, optou-se em não considerar esse dia no conjunto da cobertura midiática do desastre da Hydro. 
Nas emissoras de rádio, o meio mais potencialmente adequado a coberturas na região amazônica, pela tradição e facilidade de produção e circulação, as notícias veiculadas foram, a exemplo de todo o período analisado, pouco expressivas, com poucas ou sem fontes ouvidas. Os blogs, em sua quase totalidade regionais ou locais, indicaram no dia 23 de fevereiro um evidente alinhamento a posições institucionais oficiais.

\section{Espaço para o fato, anonimato e invisibilidade para pessoas e o lugar}

Se foi intenso e farto o espaço noticioso dado ao desastre socioambiental em Barcarena, o mesmo não se pode dizer das fontes acionadas na construção da notícia. O acionamento das vozes privilegiou quase em sua totalidade as fontes técnicas e institucionais. No dia 23 de fevereiro, quando o conjunto de fatos configurou e fez eclodir o crime ambiental do vazamento de rejeitos tóxicos da Hydro, justamente denunciado e sofrido pelos personagens e lugares invisíveis, quase nenhum espaço ou reconhecimento foi dado aos moradores e seus representantes na construção midiática.

De 230 fontes entrevistadas ou citadas pela imprensa nas 53 matérias jornalísticas produzidas naquele dia 23, menos de $10 \%$ (21) foram fontes populares, moradores, lideranças comunitárias ou representantes de entidades ou movimentos sociais/ambientais. Interessante destacar também que, de outro lado, ainda que a empresa apareça intensamente nos noticiários, o faz de forma indireta, por meio de notas, em resposta às pressões dos fatos e novas denúncias do dia.

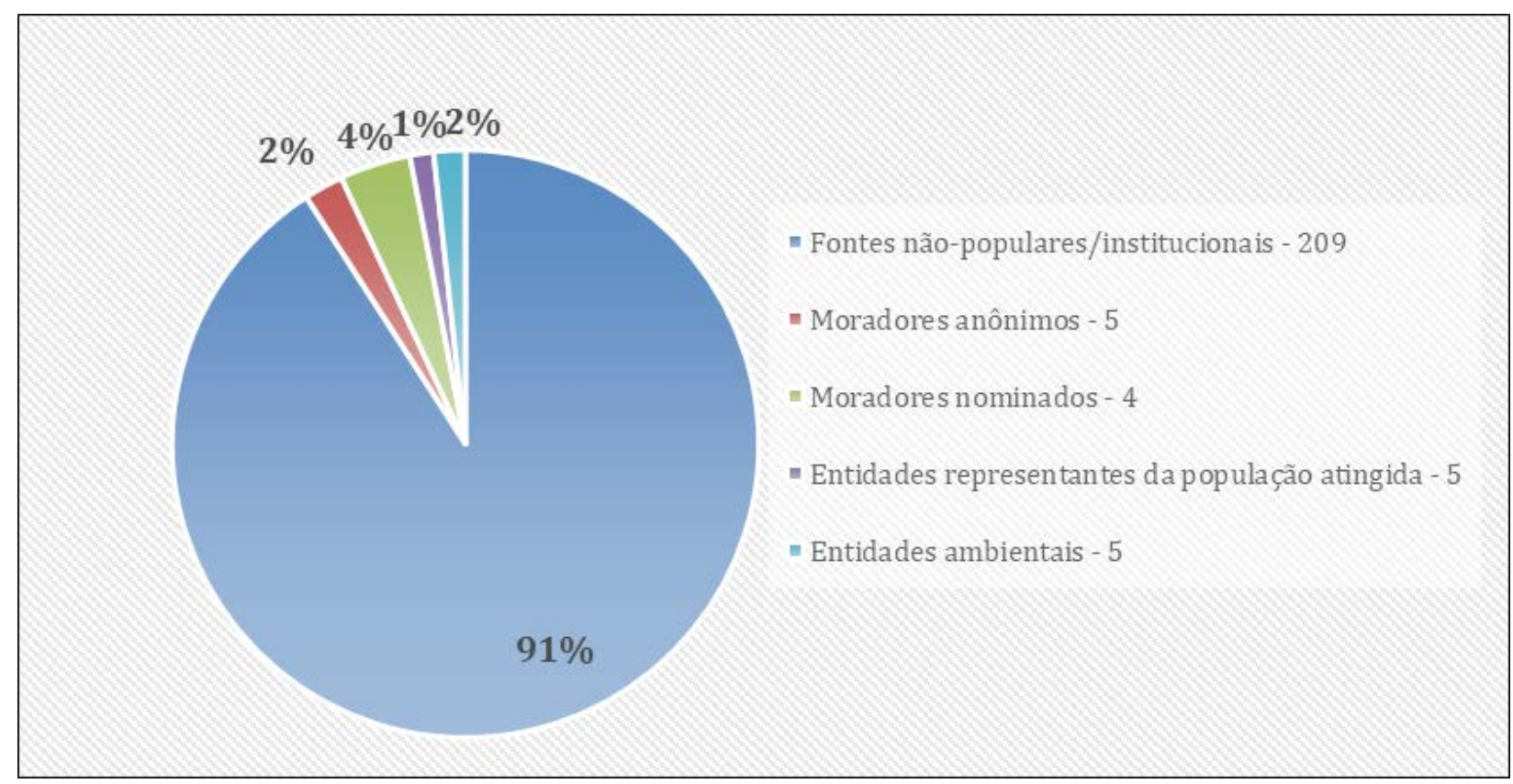

Figura 10 - Fontes na cobertura midiática do dia 23 fev. 2018 - tipo de fonte/número de vezes citada Fonte: Os autores (2019).

Considerando que vivemos em uma sociedade regida pela narrativa midiática e sob o império da imagem, considerando também que foi a televisão o meio que mais noticiou no que podemos chamar do 'dia D’ da cobertura do desastre socioambiental em foco, inclusive com maior volume de notícias nacionais, vale destacar características que se repetiram no tratamento televisivo às fontes.

As chamadas fontes especializadas, como explica Luiz Pereira Junior ${ }^{27}$, valorizadas pela expectativa da informação técnica - por exemplo, pesquisadores do Instituto Evandro Chagas ou das universidades - e as fontes oficiais, estas legitimadas pela autoridade pública da informação - como o Ministério Público do Estado do Pará ou o governo do Estado -, ou ainda as institucionais, no caso empresarial - a empresa Hydro -, apareceram sempre perfeitamente identificadas, por meio de legendas com o nome e a função 
do entrevistado, como exige a boa prática da produção e edição dos noticiosos quando a fonte não pede confidencialidade.

Já as fontes populares, no caso do desastre em Barcarena, os moradores atingidos e seus representantes, podem ser consideradas fontes fulcrais, sem as quais não há matéria, porque são as diretamente envolvidas e afetadas pelo acontecimento. Essas fontes populares aparecem em grande parte sem identificação, inominadas ou classificadas pelo caráter de vulnerabilidade da situação - 'desempregado', como escrito na legenda, em mais de um caso. O que se estende para as falas e imagens selecionadas, por situações de desespero - o homem doente, a mulher de joelhos. As fontes populares são destacadas, assim, como pessoas sem agência, sem capacidade de agir e decidir seu destino.

Importante ter claro que o tratamento às fontes entrevistadas evidencia as práticas discursivas observadas no jornalismo. Naquele 23 de fevereiro, a cobertura televisiva sobre o caso, apesar de farta e de largo alcance, ao valorizar as fontes especializadas, promove uma hierarquização e valorização do conhecimento técnico como único saber considerado válido e, portanto, legítimo, 'verdadeiro', o que por um lado, reproduz no senso comum gerado pela mídia a lógica colonial da produção do conhecimento. Por outro lado, o tratamento dado às fontes populares, tornadas anônimas ou subalternizadas, reproduz as persistentes colonialidades, que excluem e inferiorizam os mais vulneráveis, invisibilizam outras versões e visões - dos homens e mulheres pobres que moram em lugares periféricos e lutam sob constante risco. Como aponta a discussão sobre colonialidades ${ }^{10}$, o racismo estrutural, como lógica constituída desde a invasão do chamado 'Novo Mundo' pelos europeus e a escravidão na América, estrutura e organiza, por dentro, de forma interseccional, as relações de dominação na modernidade ${ }^{28}$ - a classificação social se hierarquizando por marcadores cruzados de raça, gênero, classe social, geração e território, - com efeito evidente nas assimetrias diante da divisão internacional do trabalho, da produção do conhecimento ou da justiça ambiental. Colonialidades reproduzidas e evidenciadas também, como mais uma vez se constata, na atualidade midiática.

\section{Considerações finais: repensando temporalidades e territorialidades da cobertura midiática}

A análise da cobertura midiática do desastre socioambiental ocorrido em 2018 em Barcarena, a partir dos dados trabalhados, permitiu traçar uma interpretação panorâmica e identificar uma arquitetura do acontecimento e do processo de desastre nos meios de comunicação a partir da frequência da cobertura e da aparição de fontes populares locais nas narrativas. Os achados e limites desta pesquisa abrem caminhos para estudos complementares que deem conta de um aprofundamento e um mapeamento, dessa vez, a partir dos discursos, da disputa de sentidos sobre o desastre - chegando, quem sabe, a outra camada de percepção de hierarquizações e invisibilidades. A contribuição da economia política dos meios e da ecologia política dos territórios pode ser útil para ancorar teoricamente novas reflexões.

Até onde conseguimos chegar, notamos a concentração da cobertura do desastre produzido pela Hydro Alunorte nos dois primeiros meses (fevereiro e março de 2018) e a queda acentuada no fluxo de material sobre o caso dali em diante. A aparição constante de novas ocorrências do cotidiano muitas vezes desvia a atenção midiática. Porém, sabendo que os desastres se prolongam para muito além de um evento pontual (como o vazamento em questão) e se configuram como processos estendidos e continuados, como adaptar a temporalidade da cobertura para alcançar uma perspectiva expandida?

Cabe problematizar a lógica midiática, pôr em questão os padrões que fazem a percepção jornalística não enxergar todo o processo do desastre, seus antecedentes e desdobramentos. Se um vazamento de rejeitos de bauxita nasce antes do transbordo e segue causando danos sociais e ambientais por tempo indeterminado, seria importante que a cobertura midiática estabelecesse os nexos e esticasse a produção 
noticiosa. No caso de Barcarena, onde há recorrência de desastres pelo menos desde os anos 2000, manter um acompanhamento episódico do quadro significa negligenciar o curso tanto da violência colonial quanto das vidas que resistem.

Notamos também que a repercussão do dia 23 de fevereiro, o dia "d" da cobertura, gerado por eventos institucionais, e a presença reduzida das vozes populares de comunidades e movimentos sociais sinalizam como a narrativa midiática é conduzida pelas ações de atores especializados ou oficiais, como o Instituto Evandro Chagas, o Ministério Público e o governo do Pará, enquanto atores sociais da resistência, se não são silenciados, têm no mínimo sua palavra abafada. Como deslocar a territorialidade da cobertura dessas instâncias oficiais - que assumem papéis ora de mediação, ora de apoio à luta, ora de cúmplices da violência - de modo que as comunidades locais e suas associações representativas sejam visibilizadas como protagonistas, com maior assiduidade e alcance?

Importa repensar os direcionamentos de escuta, no rumo de uma desierarquização das fontes, para mexer nas posições de poder de quem fala, para alterar a configuração do comum narrativizada pela mídia. Reivindicar da cobertura da imprensa uma postura crítica quanto à degradação neocolonial das empresas de mineração nos parece tão relevante quanto lutar pelo lugar devido, em proporção e enquadramento, para comunidades e movimentos sociais. Uma das estratégias possíveis para a descolonização das ideias é buscar conectar as lógicas midiáticas às demandas dos povos tradicionais e dos grupos subalternizados, ao tempo da vida, ao território da resistência.

\section{Referências}

1. Castro E. Estratégias de expansão territorial de empresas minerais na Amazônia, desastres socioambientais e "zonas de sacrifício". In: Castro E., Carmo E., organizadores. Dossiê desastres e crimes da mineração em Barcarena. Belém: NAEA; 2019. p.19-34.

2. Svampa M. Extrativismo neodesenvolvimentista e movimentos sociais. Um giro ecoterritorial rumo a novas alternativas? In: Dilger G, Lang M, Pereira Filho J, organizadores. Descolonizar o imaginário: debates sobre o pós-extrativismo e alternativas ao desenvolvimento. São Paulo: Fundação Rosa de Luxemburgo; 2016. p. 140-71.

3. Zouri A, Bolados P, Castro E, organizadores. Mineração na América do Sul: neoextrativismo e lutas territoriais. São Paulo: Annablume; 2016.

4. Quéré L. A dupla vida do acontecimento: por um realismo pragmatista. In: França VV; Oliveira L, organizadoras. Acontecimento: reverberações. Belo Horizonte: Autêntica; 2012. p. 21-38.

5. França V, Lopes SC. Análise do acontecimento: possibilidades metodológicas. Matrizes [Internet]. 2017 set./dez. [citado em 2020 mar. 20];11(3):71-87. Disponível em: https://www.revistas.usp.br/matrizes/ article/view/138820/137279.

6. Traquina N. Teorias do jornalismo, vol.1. Florianópolis: Insular; 2004.

7. Bourdieu P. O poder simbólico. Rio de Janeiro: Bertrand Brasil; 1989.

8. Porto M. Enquadramentos da mídia e política. In: Rubim AAC, organizador. Comunicação e política: conceitos e abordagens. Salvador: Edufba; 2004. p. 73-104.

9. Hall S, Chritcher C, Jefferson T, Clarke J, Roberts B. A produção social das notícias: o mugging nos media. In: Traquina N, organizador. Jornalismo: questões, teorias e "estórias". Lisboa: Veja; 1999. p. 224-48.

10. Quijano A. Colonialidade do poder, eurocentrismo e América Latina. In: Lander, E., coordenador. A colonialidade do saber: eurocentrismo e ciências sociais - perspectivas latinoamericanas. Buenos Aires: Clacso; 2015. [citado em 2020 mar. 18]. Disponível em: http://bibliotecavirtual.clacso.org.ar/clacso/ sursur/20100624103322/12 Quijano.pdf.

11. Hazeu MT. O não-lugar do outro: sistemas migratórios e transformações sociais em Barcarena. [tese] Belém: Universidade Federal do Pará; 2015. [citado em 2020 mar. 9]. Disponível em: https://bityli. com/1hSy6. 
12. Maia ROM. Territorialidades específicas em Barcarena confrontadas com projetos de "desenvolvimento". [tese] Belém: Universidade Federal do Pará; 2017. [citado em 2020 mar. 9]. Disponível em: http:// repositorio.ufpa.br/jspui/handle/2011/9062.

13. Almeida PR. A experiência brasileira em planejamento econômico: uma síntese histórica. In: Giacomoni J, Pagnussat JL, organizadores. Planejamento e orçamento governamental: coletânea - volume 1. Brasília: ENAP; 2006. p. 193-228.

14. Coelho MCN, Monteiro MA, Santos IC. Políticas públicas, corredores de exportação, modernização portuária, industrialização e impactos territoriais e ambientais no município de Barcarena, Pará. Novos Cadernos NAEA [Internet]. 2004 jun. [citado em 2020 mar. 12];11(1):141-78. Disponível em: https:// bityli.com/nZ3Sp.

15. Svampa M, Viale E. Maldesarollo: la Argentina del extractivismo y el despojo. Buenos Aires: Katz; 2014.

16. Ministério Público Federal, Ministério Público do Estado do Pará. Ação civil pública referente ao inquérito civil público n. 1.23.000.000661/2015-70. Belém: 2016 out. 21. [citado em 2020 mar. 15]. Disponível em: http://www.mpf.mp.br/pa/sala-de-imprensa/documentos/2016/acp-agua-potavel-barcarena.

17. Movimento Barcarena Livre. Barcarena Livre informa. 2016 dez. [citado em 2020 mar. 15];1. Disponível em: https://issuu.com/marcelhazeu/docs/informativo-bacarena livre.

18. Zhouri A. Desregulação Ambiental e Desastres da Mineração no Brasil uma Perspectiva da Ecologia Política. In: Castro E, Carmo E, organizadores. Dossiê desastres e crimes da mineração em Barcarena. Belém: NAEA; 2019. p. 43-52.

19. Nascimento SM. O Licenciamento Ambiental da Hydro Alunorte: o que há entre Desastres, Licenças e Expansões Produtivas? In: Castro E, Carmo E, organizadores. Dossiê desastres e crimes da mineração em Barcarena. Belém: NAEA; 2019. p. 91-104.

20. Gudynas E. Extractivismos en América del Sur y sus efectos derrame. Sociedad Suiza Americanistas. La Revista [Internet]. 2015 (2016). [citado em 2020 mar. 18];76:13-23. Disponível em: https://bityli.com/ Ybk7C.

21. Bueno WC. A cobertura jornalística de catástrofes ambientais: entre a vigilância e a espetacularização da notícia. C\&S - São Bernardo do Campo [Internet]. 2017 jan./abr. [citado em 2020 mar. 18];39(1):21-41. Disponível em: https://www.metodista.br/revistas/revistas-ims/index.php/CSO/article/view/6974/5716.

22. Silva G. Para pensar critérios de noticiabilidade. Estudos em Jornalismo e Mídia [Internet]. 2005 [citado em 2020 mai. 06];2(1):95-107. Disponível em: https://periodicos.ufsc.br/index.php/jornalismo/article/ viewFile/2091/1830.

23. Rocha RL. Os negócios da mídia e a comunicação da saúde. Cad. Saúde Pública [Internet]. 2016 fev [citado em 2020 em maio 05];32(2). Disponível em: https://www.scielosp.org/article/csp/2016.v32n2/ e00000616/\#.

24. Cabral EDT. Mídia no Brasil: Concentração das Comunicações e Telecomunicações. Revista EPTIC [Internet]. 2015 set.-dez. [citado em 2020 maio 06];17(3):16-28. Disponível em: http://www. labaudiovisual.com.br/labav/midia-no-brasil-concentracao-das-comunicacoes-e-telecomunicacoes/.

25. Ministério de Indústria, Comércio Exterior e Serviços [Internet]. Séries históricas. [citado em 2020 mar. 18]. Disponível em: http://www.mdic.gov.br/comercio-exterior/estatisticas-de-comercio-exterior/serieshistoricas.

26. Rodrigues JC, Hazeu MT, Nascimento SM. Como se produz desastres?: o processo de licenciamento da barragem de rejeitos da Hydro Alunorte, em Barcarena, Pará. Nucleus [Internet]. 2019 out. [citado em 2020 mar. 18];16(2):151-169. Disponível em: http://nucleus.feituverava.com.br/index.php/nucleus/ article/view/3590/3180.

27. Pereira Junior LC. A Apuração da Notícia - Métodos de Investigação na Imprensa - Col. Fazer Jornalismo. São Paulo: Vozes; 2006.

28. Grosfoguel R. Para descolonizar os estudos de economia política e os estudos pós-coloniais: Transmodernidade, pensamento de fronteira e colonialidade global. Revista Crítica de Ciências Sociais [Internet]. 2008 mar. [citado em 2020 mar. 18];80:115-47. 